\title{
PENGENALAN FLASHCARD SEBAGAI MEDIA UNTUK MENINGKATKAN KEMAMPUAN BAHASA INGGRIS
}

\author{
Sisca Wulansari Saputri \\ Universitas Banten Jaya, Jl Syech Nawawi Albantani Serang, Banten, Indonesia \\ Email: siscawulansarisaputri@unbaja.ac.id
}

\begin{abstract}
Learning abilities so that they can stimulate or encourage the learning process to be more interesting. flashcard is a media that helps in remembering and reviewing learning materials such as: definitions or terms, symbols, spelling of foreign languages, formulas, and others. The purpose of this Community Service activity is to introduce the use of Flashcards in learning English specifically to improve the understanding of the English vocabulary of students and students at SATAP SMPN 2 Kepuh, Kec. Pincincang. Community service activities by providing socialization of the application of flashcard media in learning English in order to improve the students' cognitive abilities and stimulate students to think creatively have been carried out properly. With good cooperation between the implementation team and partners, this community service activity will run as expected. With this service, teachers are expected to be able to implement flashcard media in English, as well as students can understand so that they can improve their cognitive abilities in learning English.
\end{abstract}

Keywords: English, Flashcard.

\begin{abstract}
ABSTRAK
Media pembelajaran adalah alat atau perantara dimana fungsinya yaitu sebagai penyampai pesan untuk merangsang pikiran, perasaan dan kemampuan belajar sehingga dapat merangsang atau mendorong proses belajar agar semakin menarik. flashcard adalah media yang membantu dalam mengingat dan mengkaji ulang bahan pelajaran seperti: definisi atau istilah, simbol-simbol, ejaan bahasa asing, rumusrumus, dan lain-lain. Adapun tujuan dari kegiatan Pengabdian Kepada Masyarakat ini yaitu untuk memperkenalkan penggunaan Flashcard dalam pembelajaran Bahasa Inggris khususnya untuk meningkatkan pemahaman kosakata Bahasa Inggris siswa dan siswi di SMPN SATAP Kepuh 2 Kec.Padarincang. Kegiatan pengabdian masyarakat dengan memberikan sosialisasi penerapan media flashcard dalam pembelajaran bahasa Inggris agar dapat meningkatkan kemampuan kognitif siswa dan merangsang siswa untuk berfikir kreatif telah dilaksanakan dengan baik. Dengan adanya kerjasama yang baik antara tim pelaksana dan mitra maka kegiatan pengabdian ini berjalan sesuai dengan apa yang diharapkan. Dengan dilaksanakan pengabdian ini maka diharapkan guru dapat menerapkan media flashcard dalam bahasa Inggris, begitu juga siswa dapat memahami sehingga dapat meningkatkan kemampuan kognitifnya dalam pembelajaran bahasa Inggris.
\end{abstract}

Kata Kunci: Bahasa Inggris, Flashcard

\section{PENDAHULUAN}

Bahasa Inggris yang merupakan salah satu bahasa asing yang dipergunakan di dunia internasional. Keahlian berbahasa inggris memang diperlukan untuk menguasai ilmu pengetahuan, sehingga dapat memiliki pergaulan yang luas dan karir yang baik kedepannya. Oleh karena itu semua orang termotivasi untuk belajar dan ahli dibidang ini. Lokasi pengabdian kali ini yakni di SMPN SATAP KEPUH 2. Lokasi dari Dinas Pendidikan Provinsi Banten yaitu berjarak $27.67 \mathrm{~km}$ bagi masyarakat kabupaten Serang. Pembelajaran Bahasa Inggris yang diperkenalkan sejak dini sangatlah penting, karena untuk menambah wawasan dan 
pengetahuannya dalam Bahasa Inggris. Berdasarkan hasil wawancara dengan beberapa guru dan kepala sekolah diperoleh informasi bahwa guru-guru yang mengajar Bahasa Inggris disekolah tersebut bukanlah lulusan dari FKIP khusunya Jurusan Pendidikan Bahasa Inggris, sehingga apa yang mereka ajarkan kepada anak-anak didiknya hanyalah sebatas pengetahuan yang mereka ketahui saja, selain itu letak geografis dan cara pandang masyarakat terhadap manfaat dari sekolah di wilayah tersebut sangatlah rendah, banyak siswa siswi di desa tersebut yang tidak melanjutkan ke jenjang yang lebih tinggi.

Guru-guru di sekolah tersebut telah banyak mengupayakan agar anak didik mereka dapat melanjutkan sekolah ke jenjang lebih tinggi. Salah satu faktor siswa siswa disana tidak melanjutkan yaitu rendahnya pemehaman tentang pentingnya sekolah. Bahasa Inggris disekolah tersebut adalah salah satu mata pelajaran yang tidak mereka sukai, dikarenakan siswa siswi di sekolah tersebut masih kental penggunaan bahasa ibunya (mother tongue), yaitu Bahasa Sunda. Guru mata pelajaran bahasa inggris disana mengungkapkan bahwa sangat sulit sekali mengajarkan bahasa inggris pada siswa siswi disana, sehingga kami berharap agar media flashcard adalah salah satu media yang membuat siswa siswi di SMPN SATAP KEPUH 2 menyukai atau merubah pemikiran mereka, bahwa Bahasa Inggris adalah Bahasa yang susah dipahami.Guru mata pelajaran Bahasa Inggris disana belum mempunyai wawasan dan pengetahuan tentang media flashcard sebagai media pembelajaran. Penggunaan media yang variatif dapat meningkatkan kinerja guru yang berdampak pada meningkatnya minat dan hasil belajar siswa. Dengan adanya permasalahan tentang kurangnya pengetahuan guru terhadap penggunaan media flashcard maka para guru, siswa dan kepala sekolah bersama dengan program kemitraan masyarakat (PKM) memandang perlu untuk diadakannya kegiatan pelatihan disekolah tersebut.

Menurut Indriana (2011) "media flashcard adalah media pembelajaran dalam bentuk kartu bergambar yang ukurannya sekitar $25 \times 30 \mathrm{~cm}$. Gambar yang ada pada media ini merupakan rangkaian pesan yang disajikan dengan keterangannya”. Sedangkan Chatib (2011) menjelaskan bahwa "media flashcard adalah kartu yang berisi gambar atau tulisan berhubungan dengan konsep". Definisi lain diungkapkan oleh Windura (2010), "bahwa media flashcard ataukartu kilas adalah kartu yang digunakan untuk mengingat dan mengkaji ulang dalam proses belajar". Jadi, dengan kata lain, media flashcard adalah media yang membantu dalam mengingat dan mengkaji ulang bahan pelajaran seperti: definisi atau istilah, simbolsimbol, ejaan bahasa asing, rumus-rumus, danlain-lain.

Ada beberapa kelebihan ataupun manfaat dari media flashcard yang dijelaskan oleh Indriana (2011) dan Riyana dan Susilana (2009) diantaranya; "pertama adalah mudah dibawa kemana- mana karena ukurannya yang tidak besar dan ringan. Kedua adalah praktis dalam 
membuat dan menggunakanya, sehingga kapan pun anak didik bisa belajar dengan baik menggunakan media ini. Ketiga, media flashcard juga gampang diingat karena kartu ini bergambar dan sangat menarik perhatian, memuat huruf atau angka yang simpel, sehingga merangsang otak untuk lebih lama mengingat pesan yang ada”. Media ini sangat menyenangkan untuk digunakan sebagai media pembelajaran, bahkan dapat digunakan dalam bentuk permainan. Selain kelebihan di atas Hotimah (2010) juga menjelaskan bahwa "keunggulan dari media flashcard adalah membantu kemampuan otak kanan untuk mengingat gambar dan kata sebagai komponennya.

Melalui pendapat beberapa ahli di atas maka kelebihan media flashcard adalah mudah dibawa, praktis, gampang diingat, dan menyenangkan". Adapun beberapa karakteristik dari media flashcard yang dipaparkan oleh beberapa ahli diantaranya yang dipaparkan oleh Indriana (2011) "yang pertama, ukuran flashcard sekitar $20 \times 30 \mathrm{~cm}$. Kedua gambar yang disajikan berhubungan dengan materi pembelajaran. Ketiga media ini digunakan untuk kelompok kecil kurang lebih 25 orang". Adapun karakteristik media flashcard yang efektif menurut Pujiati (2017) yaitu, "memuat tampilan huruf dalam ukuran cukup besar dan berwarna mencolok dengan latar polos, kontras dibandingkan warna huruf'. Berdasarkan pendapat beberapa ahli di atas, maka dapat disimpulkan bahwa karakteristik media flashcard merupakan kartu kombinasi antara tulisan dan gambar yang berhubungan dengan materi pelajaran, dibuat secara proporsional, dan ukurannya dapat disesuaikan dengan ruang dan jumlah siswa.

\section{METODE}

Pengabdian kepada masyrakat ini merupakan program Kuliah Kerja Mahasiswa yang rutin dilakukan setiap tahunnya. Perencanaan dimulai dengan analisis situasi disekolah tersebut kemudian mengurus surat izin dengan pihak tersebut. Selanjutnya tahap sosialiasi dan audiensi akan diadakan diruang kelas sebagaimana layaknya sistem pembelajaran yang dilakukan disekolah. Selanjutnya dilakukan tahapan pelatihan penerapan media flash card yaitu menerapkan media flash card dalam pembelajaran yang dilakukan dalam beberapa siklus sesuai dengan tingkat perkembangan anak. Kemudian tahap evaluasi akhir, observasi dan evaluasi hasil yang dicapai serta kendala yang ditemukan selama kegiatan berlangsung. Kemudian merefleksikan hasil dan kendala yang ditemukan selama kegiatan untuk dilakukan tindakan selanjutnya guna mendapat tujuan yang telah direncanakan. Adapun rencana kegiatan dalam sosialisasi permainan flash card dalam peningkatan kemampuan Berbahasa Inggris anak terdiri dari beberapa tahapan, yaitu:

1. Memperkenalkan permainan Flash card kepada anak SMPN SATAP Kepuh 2.

2. Memberikan penjelasan tentang bagaimana cara menggunakan flash card itu sendiri. 
3. Memberikan penjelasan tentang perbendaharaan kata-kata yang didalam flashcard dan memberikan contoh cara pengucapan atau pelafalan dalam bahasa inggris yang baik dan benar.

4. Menerapkan permainan flashcard dalam proses pembelajaran dikelas untuk mengetahui pemahaman siswa-siswi SMPN SATAP Kepuh 2 tentang pembelajaran flashcard dan menentukan siapa pemenangnya.

5. Dan keberlanjutan program ini dengan melakukan evaluasi guru dalam menerapkan pembelajaran flashcard dikelas agar pembelajaran tersebut menjadi lebih baik.

\section{HASIL DAN PEMBAHASAN}

Pengabdian kepada masyarakat ini dilaksanakan di SMPN SATAP Kepuh 2. Hasil yang dicapai dalam program ini berupa kegiatan pada setiap pelaksanaan dalam beberapa tahap yaitu, pendahuluan, sosialisasi, penerapan atau observasi dan evaluasi. Rangkaian pelaksanaan akan diuraikan sebagai berikut:

a. Perencanaan

Kegiatan-kegiatan yang dilakukan pada tahap ini adalah:

1. Merancang mekanisme program pengabdian masyarakat.

2. Melakukan sosialisasi kepada guru Bahasa Inggris di sekolah SMPN SATAP Kepuh 2.

3. Menyusun materi yang akan diberikan pada pelaksanaan pengabdian kepada masyarakat di SMPN SATAP Kepuh 2 Kec.padarincang.

4. Menyusun segala hal teknis yang berhubungan dengan metode atau teknik pelaksanaan pengabdian kepada masyarakat di SMPN SATAP Kepuh 2 Kec.padarincang.

b. Tindakan

Tindakan dalam kegiatan ini berupa sosialisasi flashcard dalam meningkatkan kompetensi anak. Sosialisasi ini dilakukan pada hari Senin, 26 Agustus 2019 di SMPN SATAP Kepuh 2 Kec.padarincang. Peserta sosialisasi adalah 30 orang siswa sekolah SMPN SATAP Kepuh 2 Kec.padarincang dan beberapa guru yang hadir disekolah. Adapun sosialisasi ini bertujuan untuk agar siswa dan guru mengetahui tentang media flashcard, sehingga dapat meningkatkan kompetensi siswa dan hasil belajar siswa.

c. Observasi

Dilaksanakan terhadap kemampuan siswa dalam belajar bahasa Inggris dengan menggunakan metode yang lain dari yang biasa digunakan yaitu media flashcard. Berdasarkan pengamatan selama kegiatan pengabdian berlangsung maka diperoleh hasil yang positif yaitu siswa-siswi di Sekolah SMPN SATAP Kepuh 2 Kec.padarincang terlihat antusias terhadap materi yang diberikan oleh tim pelaksana dan mampu mengikuti setiap 
materi yang diberikan dengan menggunakan media flash card. Selamakegiatan berlangsung terdapat kendala yaitu terbatasnya waktu selama kegiatan berlangsung.

d. Evaluasi

Untuk mengatasi segala kendala yang terjadi selama kegiatan berlangsung maka diperlukan evaluasi, salah satunya dengan cara memantau kembali kegiatan pembelajaran dengan flashcard, sehingga proses pembelajaran ini menjadi lebih baik dan meningkatkan hasil belajar siswa kedepannya.

e. Refleksi

Refleksi adalah kegiatan yang dilakukan untuk mengetahui sejauh mana kekurangan dan juga kelebihan terhadap kegiatan yang sudah dilakukan. Hasil refleksi sangat perlu dilakukan suatu upaya untuk membantu meningkatkan kompetensi anak dalam menggunakan media belajar untuk meningkatkan hasil belajar siswa.
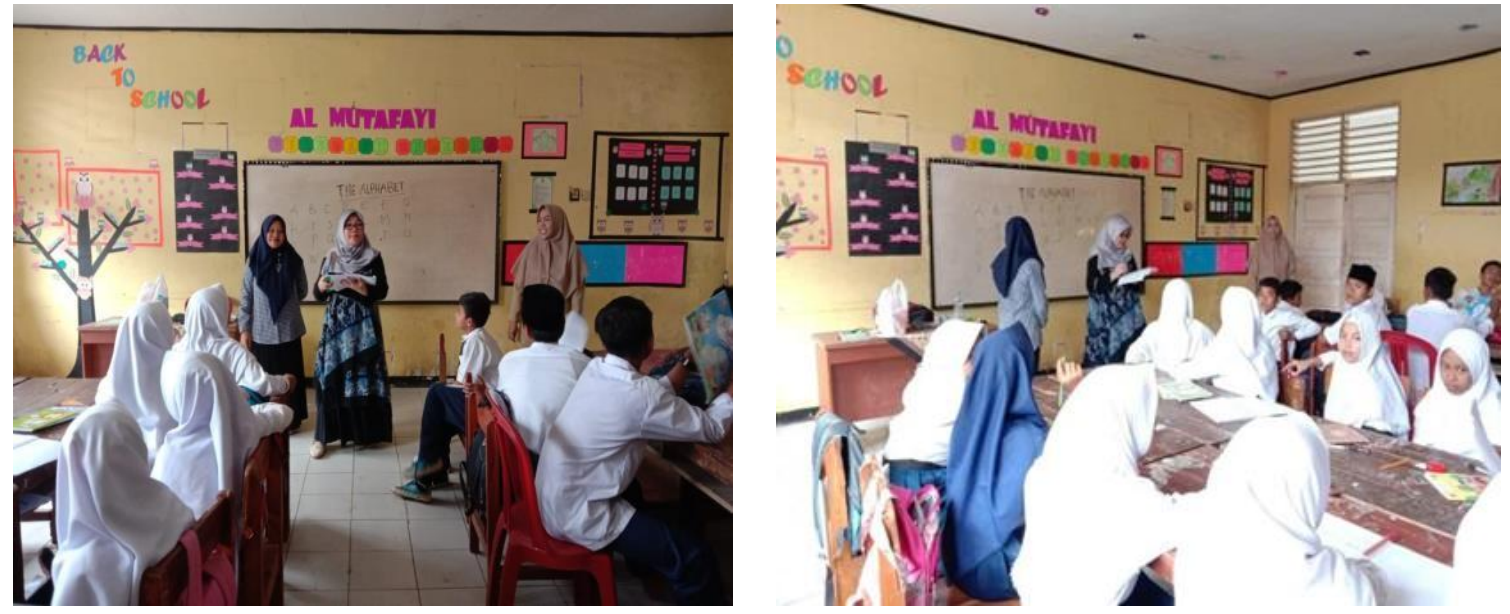

\section{Gambar 1. Kegiatan yang Dilaksanakan}

Kegiatan pengabdian masyarakat yang dilaksanakan pada siswa-siswa SMPN SATAP Kepuh 2 Kec.padarincang berjalan dengan lancar dan baik. Hal ini dapat dilihat dari antusias dan keaktifan siswa selama mengikuti kegiatan pengabdian ini. Kendala-kendala yang dihadapi dalam pelaksanaan pengabdian masyarakat ini adalah masalah waktu pelaksanan yang singkat dan terbatas. Walaupun begitu kendala yang terjadi dapat diselesaikan dengan baik dengan solusi menyesuaikan waktu antara pihak sekolah mitra (SMPN SATAP Kepuh 2 Kec.padarincang) dengan pihak pelaksanaan pengabdian masyarakat dari Universitas Banten Jaya, sehingga pelaksanaan dapat berjalan dengan baik. 


\section{KESIMPULAN}

Kegiatan pengabdian masyarakat dengan memberikan sosialisasi penerapan media flashcard dalam bahasa Inggris untuk meningkatkan kemampuan kognitif siswa dan merangsang siswa untuk berfikir kreatif telah dilaksanakan dengan baik. Dengan adanya kerjasama yang baik antara tim pelaksana dan mitra maka kegiatan pengabdian ini berjalan sesuai dengan apa yang diharapkan. Dengan dilaksanakan pengabdian ini maka diharapkan guru dapat menerapkan media flashcard dalam bahasa Inggris, begitu juga siswa dapat memahamidan meningkatkan kemampuan kognitif anak belajar bahasa Inggris.

\section{DAFTAR PUSTAKA}

Chatib, M. (2011). Gurunya manusia: menjadikan Semua Anak Istimewa dan Semua Anak Juara. Bandung: PT Mizan Pustaka.

Indriana, D. (2011). Ragam Alat Bantu Media Pengajaran. Jogjakarta: DIVA Press.

Pujiati, M. (2017). Cara Mudah Mengajar Anak Membaca: Mengajari Anak Membaca Menjadi Ringan dan Menyenangkan. Nauka Publishing.

Riyana, C \& Susilana, R. (2009). Media pembelajaran. Bandung: CV Wacana Prima.

Windura, S. (2010). Memory Champion School: Rahasia mengingat materi pelajaran apa saja. Jakarta: PT Elex Media Komputindo. 